\title{
窒素 固定への試み
}

\section{内田安 三 \\ Yasuzo UCHIDA}

東京大学工学部

\section{1. は じめ に}

自然界，とくに生物の世界でいとなまれている多くの 特異な化学反応を解明し，それをわれわれの手の内に具 現化することは, 生物化学者をはじめ科学者の大きな夢 の 1 つであ. 光合成, あるいは窒素固定といった同化 の反応も，その代表的なものといえる．自然界でのこの ような特異な現象を考究する場合，研究者のおの沶のの 分野での意図や方法論で多様のアプローチがあるわけで, 現象の正確な機構解明, 具現化といった方法以外に，た とえばその諸要因を抽象化し，類似のパターンとして具 現化するといら場合もある。いずれにせよ，異なった分 野, 手法でのアプローチは互いにかえって示唆の多いも のである. 本題目でとりあげた窒素固定への試みも，そ のよらな意味で, いわゆる合成化学者側からの眼で, し かも多分に筆者の主観のままに述べさせていただくこと にするななお，最近この分野に対する総説などもかなり 報ぜられているので, 参考にされたい(1)。

窒素分子からアンモニアの合成は, Haber Bosch 法 の確立によって，現在はきわめて完成度の高い工業技術 となっている.これは, 基本的には, 鉄, モリブデン, タングステン，オスミウムなどの遷移金属またはアルカ リ金属などからなる触媒を用いるものであるが，触媒の 改良にもかかわらず，アンモニア合成の条件は 400〜 $500^{\circ} \mathrm{C}, 100 \sim 1,000$ 気圧と, かなり苛酷なものである. 温和な条件下での活性化の 1 つの手段として, 電子線, 紫外線, プラズマ照射といった物理的励起を行ない, 窒 素分子をイオン化, 開裂させる研究も知られているが, 選択的に一定の反応を行ないらるものではない. 古典的 な意味で不活性分子とされている窒素分子をいかにたく みに反応させ, 温和な条件で, たとえばヒドラジンを合
成し，各種有機含窒素化合物を合成しらるか。これは工 業技術としても大きな興味の対象である。一方，自然界 ではある種の藻類で, また根粒バクテリヤで, 窒素の同 化がきわめて温和かつたくみに行なわれている。この機 作は一体何であろらか。これが 1 つの問題の接点となる. 窒素同化に主要な役割を果たす酵素系, ナイトロゲナー ゼは, 非へム鉄イオン, モリブデン・サルファイド構造 を含んだ複合蛋白錯体で，窒素分子のみならず, $\mathrm{NO}_{2}$, $\mathrm{N}_{3}{ }^{-}$, アルケン, $\mathrm{HCN}$, ニトリル, イソニトリルなどの 還元, 水素の発生にあずかるものとして知られている(2). 反応のサイクルには，もちろん ATP などの関与はある が，きわめて概念的には，たとえば図1 のモデルで提 唱されるように機作すると考えられよう．との機構に関 してはいくつかのモデルがあるが，いずれにせよ，窒素 分子は鉄，モリブデン，または鉄一モリブデンといった 活性点に配位, 結合し, さらにこれに活性化された水素, 颃そらく金属ハイドライドが反応して逐次還元され，ア ンモニアへと導かれるとしてよい.

窒素分子に似たアセチレン, 一酸化炭素, またはニト リルなどが存在すると窒素固定が阻害されることは，こ

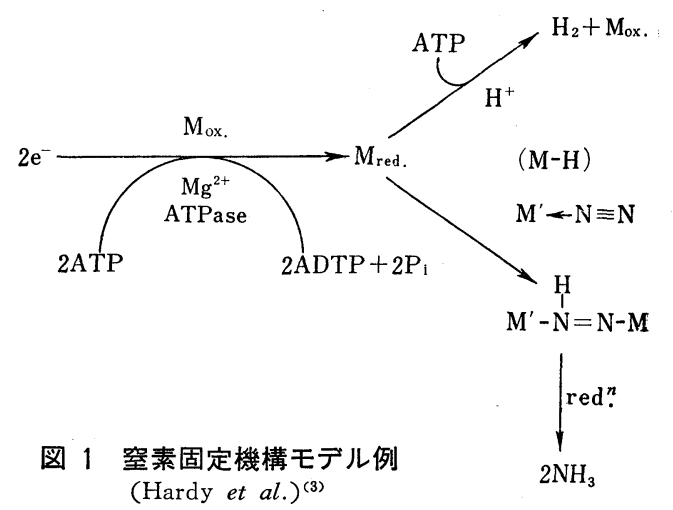


れらの分子が窒素の代わりに酵素の site を占めるため と考えれば，上記機構を了解するのに都合がよい，ナイ トロゲナーゼでの金属の役割, とくに窒素分子との関与 を明確にすることが，温和な窒素固定への第一歩となる。

窒素分子が金属表面に比較的容易に吸着されることは， よく知られた事実である。ニッケル表面では, 窒素分子 はその一方の原子でニッケル原子に吸着する。このよう な化学吸着状態での IR スペクトルは $2202 \mathrm{~cm}^{-1}$ に吸収 があり (4)，これは遊離の窒素の場合より約 $100 \mathrm{~cm}^{-1}$ ほ ど低波長にあることから，吸着による活性化はかなり弱 いものと了解されている.イリジウム, タングステン, タンタルなどの金属でむ，その表面に窒素が吸着しやす く，たと学ば金属精錬の際，表面に窒素化合物を作らな いようにその加工技術を指示している場合もある。また， リチウムは窒素分子と反応して容易に LiN となり, こ れが窒素ラインで不注意にリチウムを用いた場合, 化学 実験室での爆発事故の原因となることもょく注意される，

以上の多様な知見を背景として, 合成化学的に温和な 条件下で窒素分子を活性化するためには，まず適当な金 属を選び，これに配位子が結合した活性金属錯体を合成 し，これと窒素分子との作用を検討することが，ナイト ロゲナーゼの活性点の機作への 1 つのアプローチとなる 次に, このような金属-窒素化合物の反応性, とくに還 元または反応系のリサイクルといった問題が，これに付 随するわけである。

窒素固定のこのような試みは最近 5 年間, とくに無機 合成化学者, 触媒化学者などを中心にさかんとなった。 以下, これらの研究の発端と現状をでの推移を述べる.

\section{2. 窒素固定への緒}

\section{1 有機金属触媒系での窒素からアンモニアの合成}

1964 年, Vol'pin は各種の遷移金属化合物之還元剂を 組み合わせた系に窒素ガスを導入し，さらにこれを加水 分解すると, 微量ではあるが常温かつ比較的低圧で窒素 分子からアンモニアへの還元が行なわれることを見いだ した(5).一例をあげると, ェーテルを溶媒として $\mathrm{CrCl}_{3}$ を $\mathrm{LiAlH}_{4}$ で還元する.この際, 反応を常圧の窒素ふん い気下で行ない, 8 10 時間後, 塩酸で加水分解すると, $\mathrm{CrCl}_{3} 1$ モル当り 0.02 モルのアンモニアが生成する. 窒素圧を 150 気圧にするとアンモニアの生成量は 0.07 モルになる。また，還元剤にグリニャール試薬 $\left(\mathrm{C}_{2} \mathrm{H}_{5}\right.$ $\mathrm{MgBr})$ を用いると 0.17 モルに增加する. Vol'pin はこ の種の反応を各種遷移金属, 還元剤の組合せで検討して おり, 表1に示すように, $\mathrm{Cr}$ III, $\mathrm{Mov}^{\mathrm{v}}, \mathrm{Wv}^{\mathrm{vI}}, \mathrm{Ti}^{\mathrm{iv}}$ および
表 $1 \mathbf{M e C l}_{n}+\mathrm{C}_{2} \mathbf{H}_{5} \mathbf{M g B r}$ 系による窒素の固定

\begin{tabular}{|c|c|c|c|}
\hline $\mathrm{MeCl}_{n}$ & $\begin{array}{c}\text { 塩 } 1 \text { モル当りの } \\
\mathrm{NH}_{3} \text { 収澹 }\end{array}$ & $\mathrm{MeCl}_{n}$ & $\begin{array}{c}\text { 塩 } 1 \text { モル当りの } \\
\mathrm{NH}_{3} \text { 収率 }\end{array}$ \\
\hline $\mathrm{TiCl}_{4}$ & 0.12 & $\mathrm{FeCl}_{3}$ & 0.09 \\
\hline $\mathrm{CrCl}_{3}$ & 0.17 & $\mathrm{CoCl}_{2}$ & 0 \\
\hline $\mathrm{MoCl}_{5}$ & 0.08 & $\mathrm{NiCl}_{2}$ & 0 \\
\hline $\mathrm{WCl}_{6}$ & 0.15 & $\mathrm{PdCl}_{2}$ & 0 \\
\hline $\mathrm{MnCl}_{2}$ & 0 & $\mathrm{CuCl}$ & 0 \\
\hline
\end{tabular}

温度 $20^{\circ} \mathrm{C}$, 空素圧 150 気圧.

$\mathrm{Fe}$ III の塩化物が高い活性を示し，一方, $\mathrm{Mn}$ II, $\mathrm{Co}^{\mathrm{II}}, \mathrm{Ni}^{\mathrm{II}}$, $\mathrm{Pd}^{\mathrm{II}}, \mathrm{Cu}^{\mathrm{I}}$ の塩化物では活性が少ないとしている. この反 応系は, さらに ${ }^{15} \mathrm{~N}$ を含む窒素ガスで検討され, 生成ア ンモニア中の ${ }^{15} \mathrm{~N}$ 含量がもとの窒素分子と同量の含量 であることから，反応ふんい気の窒素分子が反応にあず かることを確認している，またこの場合，水素ガスを共 存させてもアンモニアへの還元にはあずからず，金属に あらかじめ形成されたハイドライド水素, 溶媒, 加水分 解試薬からの水素がこれに関与していることが認められ た。

遷移金属塩または錯塩を, グリニャール試薬, 有機ア ルミニウムなどの還元剤で還元させる系は，低原子価系 の金属化合物を合成する常法手段で，一般にこれらの手 法でオレフィン, アセチレン錯体, または多くの低原子 価金属錯体が得られる。とくに， $\mathrm{TiCl}_{4}-\mathrm{AlEt}_{3}$ の系は Ziegler 触媒として最もポピュラーなもので (表 2)，こ

表 $2 \mathrm{Ti}$ 系による窒素の固定

\begin{tabular}{c|c|c|c}
\hline \multirow{2}{*}{$\mathrm{Ti}$ 化合物 } & \multicolumn{3}{|c}{ 塩 1 モル当りの $\mathrm{NH}_{3}$ 収率 } \\
\cline { 2 - 4 } & $\mathrm{C}_{2} \mathrm{H}_{5} \mathrm{MgBr}$ & $n-\mathrm{C}_{4} \mathrm{H}_{9} \mathrm{Li}$ & (iso- $\left.\mathrm{C}_{4} \mathrm{H}_{9}\right)_{3} \mathrm{Al}$ \\
\hline $\mathrm{TiCl}_{4}$ & 0.12 & 0.29 & 0.32 \\
$\mathrm{C}_{5} \mathrm{H}_{5} \mathrm{TiCl}_{3}$ & 0.23 & 0.07 & 0.15 \\
$\left(\mathrm{C}_{5} \mathrm{H}_{5}\right)_{2} \mathrm{TiCl}_{2}$ & 0.90 & 0.50 & 0 \\
\hline
\end{tabular}

温度 $20^{\circ} \mathrm{C}$, 窒素圧 150 気圧.

の種の反応は, 過去十数年の間, 多くの研究者によって 手がけられ，その数は 100 万回を越えるであろう。しか も, これらの反応が空気海感なため, 一般窒素ガス ふんい気下で処理するのが常識である.

遷移金属化合物亡有機金属還元剂の反応は，その種類 によって多様であるが, 例をコバルトアセチルアセトナ 一ト $\left(\mathrm{Co}(\mathrm{acac})_{3}\right)$ と $\mathrm{AlEt}_{3}$ の系についてふれる.

$\mathrm{Co}$ II $(\mathrm{acac})_{3}$ をベンゼンに溶解させ，これに $\mathrm{AlEt}_{3}$ を 加光ると，CoIII はまず $\mathrm{Co}^{\mathrm{II}}$ 、, 次に $\mathrm{Co}^{0}$ へと還元され る.

$$
\begin{aligned}
\mathrm{Co}(\mathrm{acac})_{3}+\mathrm{AlEt}_{3} \longrightarrow \mathrm{Co}(\mathrm{acac})_{2}+\mathrm{AlEt}_{2}(\mathrm{acac}) \\
+1 / 2\left(\mathrm{C}_{2} \mathrm{H}_{4}+\mathrm{C}_{2} \mathrm{H}_{6}\right) \\
\mathrm{Co}(\mathrm{acac})_{2}+2 \mathrm{AlEt}_{3} \longrightarrow \mathrm{Co}^{0}+\mathrm{AlEt}_{2}(\mathrm{acac}) \\
+\mathrm{C}_{2} \mathrm{H}_{4}+\mathrm{C}_{2} \mathrm{H}_{6}
\end{aligned}
$$


ここでまず CoIII は対イオンであるアセチルアセト ンと $\mathrm{AlEt}_{3}$ のエチル基の交換をしこのようにしてでき た Co-Et 結合が不安定なため, ただちに分解して CoII と $\mathrm{C}_{2} \mathrm{H}_{4}, \mathrm{C}_{2} \mathrm{H}_{6}$ になる. この反応がさらに進むと原子状 コバルトまで還元されるが, Co-Et 結合の切断の際, エ チレンとして分解しコバルトハイドライドが形成するこ とも認められる．原子状に還元されたュバルトは，この 系では $\mathrm{AlEt}_{2}$ (acac) に強く溶媒和されてかなりの間均一 飞保たれるが, 逐次会合して超常磁性を示すような会合 系から，さらにコバルト金属となって沈殿する。これは， 古くはラネーコバルのような活性コバルトの合成法で むあり， $\mathrm{Co}(\mathrm{acac})_{3}$ の代わりに $\mathrm{CoCl}_{3}$ を用いると $\mathrm{AlEt}_{3}$ からは $\mathrm{AlEt}_{2} \mathrm{Cl}$ が生じ, これの $\mathrm{Co}^{0}$ に対する溶媒和が 弱いため，この場合はただちに金属コバルトとして沈殿 する。この還元系に適当な配位子, たと究ばジピリジル を入れておくと, 反応過程の物質, コバルトアルキルが 取り出せる(6).このような物質はオレフィン, ジェン,

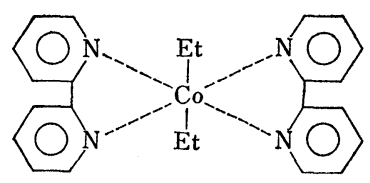

アセチレン, 一酸化炭素といった電子供与性の化合物と 容易に反応して, 新しくこれらの配位した物質となる.

金属種，還元剤により，金属が何価まで還元されるか はさまざまで, $\mathrm{TiCl}_{4}-\mathrm{AlEt}_{3}$ などでは $\mathrm{Ti}$ 忹, $\mathrm{Ti}$ 표 といっ た状態が多く推定されている.Zieg1r 触媒は周知のごと く，このような反応でできたーTi-R 構造 (R: エチル 基）のオレフィンが $\mathrm{Ti}$ への配位を経て聥入してゆくこ とにより，重合活性を示すわけである。

Vol'pin の卓越した着想は，オレフィン，アセチレン， 一酸化炭素などと反応しやすい系で, だれもが空素ふん い気で行なっている反応を， $\mathrm{N} \equiv \mathrm{N}$ がこれらの分子と同 様に活性状態の金属に配位, 結合するのではないかと疑 い, かつ加水分解で微少量のアンモニアの確認を行なっ たところにある.この研究の発表以後, 多くの研究者が その機構を検討し，また反応試薬を変えてその効率をあ 訪る努力をしているが，これは後述することにする。

\section{2 窒素を配位させた金属錯体の合成}

Vol'pin の用いた触媒系から空素分子がどのように活 性化されるか，またその形はいかなるものか，を確認す ることは困難なことであった，当時，窒素分子自身の金 属原子への配位は金属表面のそれを除いては未知であり， 分子状窒素之金属原子の結合をもった化合物, 窒素錯体 の合成とその反応性の検討が 1つの焦点となった. 1965
年, カナダの Allen, Senoff(7) は, $\mathrm{RuCl}_{3}$ むたは $\mathrm{K}_{2}$ $\left[\mathrm{Ru}^{\mathrm{II}} \mathrm{Cl}_{5} \cdot \mathrm{H}_{2} \mathrm{O}\right]$ とヒドラジンヒドラートを反応させるこ とにより, $\left[\mathrm{Ru}\left(\mathrm{NH}_{3}\right)_{5} \mathrm{~N}_{2}\right] \mathrm{X}\left(\mathrm{X}=\mathrm{Br}^{-}, \mathrm{I}^{-}, \mathrm{BF}_{4}^{-}, \mathrm{PF}_{6}^{-}\right)$と いった分子状窒素の配位した $\mathrm{Ru}$ 錯体を合成することに 成功した. この化合物は IR スペクトルで 2100〜2170 $\mathrm{cm}^{-1}$ に強く鋭い吸収を示し，これが金属に配位した窒 素分子の伸縮振動と同定された.この吸収は, 遊離の窒 素分子の $\nu_{\mathrm{N}_{2}} 2331 \mathrm{~cm}^{-1}$ より約 $200 \mathrm{~cm}^{-1}$ 低波長にシフ トしていることから, 金属カルボニルの場合と同様に, 窒素分子の $\sigma$ 性電子対の金属の空軌道への電子供与 (donation) とともに, 金属から窒素分子軌道への供与 (back donation, $d \pi-p \pi$ ) があることを示している.こ の錯体は空気中で比較的安定であるが，水により急速に 分解する。また，高真空下の加熱，95\% 硫酸との反応 などで窒素ガスを遊離する。

Allen は $\left[\mathrm{Ru}\left(\mathrm{NH}_{3}\right)_{5} \mathrm{~N}_{2}\right] \mathrm{I}_{2}$ に $\mathrm{NaBH}_{4}$ および $\mathrm{NaOH}$ 水溶液を反応させるとアンモニアが生じると報じたが, これは Shilov らの追試により(8)アンモニアは生成しな いと結論された。なお，この錯体は Bottomley らによ りX線解析が行なわれ，Ru-N $\equiv \mathrm{N}$ の結合はほぼ值線状で あることが認められた。

酵素のようにガス状の窒素分子を直接とりこんで, 活 性化した状態の窒素錯体を合成するといら次のステップ は，むしろ偶然といってよい形で登場した，前述のよう に，遷移金属化合物一有機金属触媒系は立体規則性重合 触媒系として知られているが，筆者の研究室でも，この 系に, とくにブタジェン, イソプレンの重合触媒系に適 当な電子供与体を加え, 重合活性を低下して構造の規制 された二, 三量体, すなわちテルペン類似物質の合成触 媒の研究に従事していた。 また，そのような触媒系から 活性な $\mathrm{Fe}-, \mathrm{Co}-, \mathrm{Ni}-ア ル キ ル$ 錯体の合成を東工大池田, 山本研と共同して研究していた。

その中で，ブタジェンを鎖状二量化する反応系から触 媒錯体を合成するため, $\mathrm{Co}(\mathrm{acac})_{3}-\mathrm{AlEt}_{2}(\mathrm{OEt})$ にトリ フェニルホスフィン $\left(\mathrm{PPh}_{3}\right)$ を加え, $\mathrm{Et}_{n} \cdot \mathrm{Co}\left(\mathrm{PPh}_{3}\right)_{4}$ が できることを期待していたが，生成する橙黄色の生成物 にはエチル基は存在せず, IR スペクトルで $2088 \mathrm{~cm}^{-1}$ に吸収を示すものであった，コバルトは比較的容易に八 イドライドを形成しやすいので, これは $\mathrm{HCo}\left(\mathrm{PPh}_{3}\right)_{n}$ といったものではないかと構造未定のままかなり放置し ていた. しかし, Allen らの報告などから推し,これが反 応に用いた窒素ライン中の窒素ガスが吸着, 配位された のではないかといら山本氏の指摘があり, 生成物の精製, 確認をしたところ，Co- $\mathrm{N} \equiv \mathrm{N}$ 構造を持つ物質であること 
が判明した。両研究室での合成試薬などの若干の差異で $\mathrm{Co}\left(\mathrm{PPh}_{3}\right)_{3} \mathrm{~N}_{2}{ }^{(9)}, \mathrm{Co}\left(\mathrm{PPh}_{3}\right)_{3} \mathrm{~N}_{2} \cdot \mathrm{H}^{(10)}$ といった一連の窒 素錯体が見いだされ，さらに，ガス状窒素を脱吸着する 化合物として $\mathrm{Co}\left(\mathrm{PPh}_{3}\right)_{3} \mathrm{H}_{3 \text { or } 2}$ といったるのが確認され た. 当時イタリヤの Sacco は, $\mathrm{CoX}_{2} \mathrm{~L}_{2}(\mathrm{X}=\mathrm{Cl}, \mathrm{Br}, \mathrm{I} ; \mathrm{L}$ $\left.=\mathrm{PPh}_{3}, \mathrm{PEtPh}_{2}\right)$ をェタノール溶媒で $\mathrm{PPh}_{3}, \mathrm{PEtPh}_{2}$ な ぞの存在下で $\mathrm{NaBH}_{4}$ を反応させ，ハイドライド錯体 $\mathrm{CoH}_{3} \mathrm{~L}_{3}$ の合成を行なっていたが, かなりの間, 構造不 定のままにとどまっていた。これは，生成物が窒素ライ ン中の窒素を一部含むため, 混合物となったことにもよ ると思うが，筆者らの報告に相ついで $\mathrm{CoH}_{3} \mathrm{~L}_{3}$ の合成を 報じ，これが窒素と叮逆的に反応することを報じてい $\mho^{(11)}$.

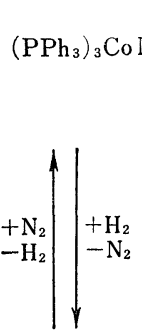

$\left(\mathrm{PPh}_{3}\right)_{3} \mathrm{CoH}_{3}$
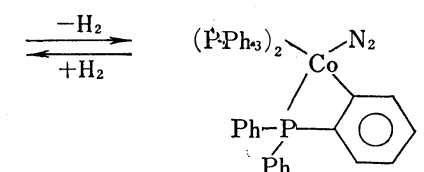
$\begin{aligned} & +\mathrm{N}_{2} \\ & -\mathrm{H}_{2}\end{aligned} \mid \begin{aligned} & +\mathrm{H}_{2} \\ & -\mathrm{N}_{2}\end{aligned}$

$\left(\mathrm{PPh}_{3}\right)_{2}$

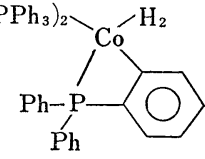

$\mathrm{Co}\left(\mathrm{PPh}_{3}\right)_{3} \mathrm{~N}_{2}$ または $\mathrm{Co}\left(\mathrm{PPh}_{3}\right)_{3} \mathrm{~N}_{2} \cdot \mathrm{H}$ のこれら錯体の 構造が論じられたが，のちに Parshall らの重水素を用 いた交換反応などにより(12)，上図のような平衡反応が 生じるため，多種の錯体が得られたので あろうと推論されている。

$\mathrm{Co}\left(\mathrm{PPh}_{3}\right)_{3} \mathrm{~N}_{2} \cdot \mathrm{H}$ の構造解析は Ibers らにより行なわれ(13)，図２のようにCo$\mathrm{N} \equiv \mathrm{N}$ がほ潘直線的に結合し， $\mathrm{N}_{2}$ のトラ ンス位にハイドライド水素が存在すると されている.

余談であるが，当時，筆者らの従事し ていたジェン化合物の二量化，三量化反 応の先駆的な科学者である Prof. Wilke らも，まったく同様な触媒系を反応させ た経験があったが，ドイッでは低原子価 金属錯体の合成は窒素ラインではなく， もっぱらアルゴンライン（これはわれわ れにとって非常にぜいたくなことである が）を用いているそらで，そのため窒素 錯体の生成を認め觉なかったそうである。 $\mathrm{Co}\left(\mathrm{PPh}_{3}\right)_{3} \mathrm{~N}_{2} \cdot \mathrm{H}$ は水素と交換する以

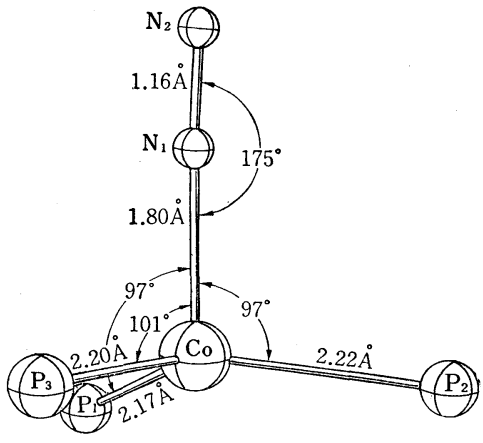

図 $2 \operatorname{CoH}\left(\mathbf{N}_{2}\right)\left(\mathbf{P P h}_{3}\right)_{3}$ の構造 ${ }^{(13)}$

$\angle \mathrm{P}_{1}-\mathrm{Co}-\mathrm{P}_{2}=115.5^{\circ}, \angle \mathrm{P}_{1}-\mathrm{Co}-\mathrm{P}_{3}=114.6^{\circ}, \angle \mathrm{P}_{2}-\mathrm{Co}-\mathrm{P}_{3}$ $=123.3^{\circ}$ (すべて $\pm 0.6^{\circ}$ ).

図中の距離拉よび角の標準偏差 : Co-P, $0.02 \AA$; Co-N および N-N, $0.04 \AA$ A $, \angle \mathrm{N}-\mathrm{Co}-\mathrm{P}, 1^{\circ} ; \angle \mathrm{N}-\mathrm{N}-\mathrm{Co}, 4^{\circ}$

外にェチレン,アンモニアなどとも可逆的に交換反応を するが，コバルトに配位した窒素を還元することには成 功していない.

\section{3. 窒素固定への研究の展開}

前述の研究がいわば緒となり，近年アンモニア合成の 触媒系の改善，窒素錯体の合成などが活発に行なわれて いる.

\section{1 窒素固定系の研究}

Vol'pin 以後, 同様の形式で窒素を温和な条件下で反 応させる系として報じられているものを表了に示した． また，アンモニアの生成以外に，たとえば反応過程でヒ

表 3 窒素を固定する系

\begin{tabular}{|c|c|c|}
\hline 応 & 条 & $\begin{array}{l}\text { 塩 } 1 \text { モル当りの } \\
\mathrm{NH}_{3} \text { 収率 } \\
\end{array}$ \\
\hline $\begin{array}{l}\mathrm{TiCl}_{4}+\mathrm{Mg}+\mathrm{I}_{2} \\
\left(\mathrm{C}_{5} \mathrm{H}_{5}\right)_{2} \mathrm{TiCl}_{2}+\mathrm{Mg}+\mathrm{I}_{2} \\
\mathrm{CrCl}_{3}+\mathrm{Mg}+\mathrm{I}_{2}\end{array}$ & $\begin{array}{lr}\text { 温 度 } & 20^{\circ} \mathrm{C} \\
\text { 窒素压 } & 150 \text { 気圧 }\end{array}$ & $\begin{array}{l}1.32 \\
1.14 \\
0.65\end{array}$ \\
\hline $\left.\begin{array}{l}\mathrm{TiCl}_{4} \\
\mathrm{VOSO}_{4} \\
\mathrm{~K}_{2} \mathrm{Cr}_{2} \mathrm{O}_{7}\end{array}\right\}+\left\{\begin{array}{l}\mathrm{Zn} \\
\mathrm{Zn}-\mathrm{Hg}\end{array}\right.$ & 酸性水溶液中 & $0.02 \sim 0.04$ \\
\hline 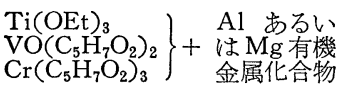 & $\begin{array}{l}\text { 窒素圧 } 38 \sim 100 \text { 気圧 } \\
\text { 水素圧 } 32 \sim 50 \text { 気圧 }\end{array}$ & $0.01 \sim 0.05$ \\
\hline $\begin{array}{l}\left(\mathrm{Ph}_{3} \mathrm{P}\right)_{2} \mathrm{TiCl}_{4}+(\text { iso- } \mathrm{Bu})_{3} \mathrm{Al} \\
\left(\mathrm{Ph}_{3} \mathrm{P}\right)_{2} \mathrm{FeCl}_{3}+\mathrm{EtMgBr}\end{array}$ & $\begin{array}{cc}\text { 室 } & \text { 温 } \\
\text { 窒素圧 } & 150 \text { 気圧 }\end{array}$ & $\begin{array}{l}0.12 \\
0.03\end{array}$ \\
\hline$\left(\mathrm{C}_{5} \mathrm{H}_{5}\right)_{2} \mathrm{TiCl}_{2}+\mathrm{C}_{6} \mathrm{H}_{5} \mathrm{Li}$ & $\begin{array}{lr}\text { 温 度 } & 20^{\circ} \mathrm{C} \\
\text { 䇪素圧 } & 100 \text { 気圧 }\end{array}$ & $\begin{array}{ll}0.15 \text { モル } & \mathrm{C}_{6} \mathrm{H}_{5} \mathrm{NH}_{2} \\
0.65 \text { モル } & \mathrm{NH}_{3}\end{array}$ \\
\hline $\begin{array}{l}\mathrm{TiCl}_{4}+\mathrm{K}(\mathrm{O}-\mathrm{tBu})+\mathrm{K} \\
\left(\mathrm{C}_{5} \mathrm{H}_{5}\right)_{2} \mathrm{TiCl}_{2}+\mathrm{NaNp}\end{array}$ & $\begin{array}{c}\text { 室 } \\
\text { 窒素圧 常 } \\
\end{array}$ & $0.10 \sim 0.15$ \\
\hline $\left.\begin{array}{l}\mathrm{VCl}_{3} \\
\mathrm{CrCl}_{3} \\
\mathrm{TiCl}_{4}\end{array}\right\}+\mathrm{LiNp}$ & $\begin{array}{lr}\text { 温 度 } & 20^{\circ} \mathrm{C} \\
\text { 窒素圧 } & 120 \text { 気压 }\end{array}$ & $0.9 \sim 2.0$ \\
\hline
\end{tabular}

$\mathrm{C}_{5} \mathrm{H}_{5}=$ cyclopentadienyl, $\mathrm{Np}=$ naphthalide. 
ドラジンを認めた報告(14)，また $\mathrm{C}_{6} \mathrm{H}_{5} \mathrm{Li}-\left(\mathrm{C}_{5} \mathrm{H}_{5}\right)_{2} \mathrm{TiCl}_{2}$ 系 で窒素を固定すると少量のアニリンが生成すること(15), などは注目に価する。

遷移金属塩-還元剤の系での研究は，その中心がチタ ンについて, 機構解明が精力的に行なわれてきた. $\mathrm{TiCl}_{4}$ 系で㤆応系が不均一のため, むしろ均一系になる $\left(\mathrm{C}_{5} \mathrm{H}_{5}\right)_{2} \mathrm{TiCl}_{2}$ が多用される. Pratt ら ${ }^{(16)}$ は $\left(\mathrm{C}_{5} \mathrm{H}_{5}\right)_{2} \mathrm{Ti}$ $\mathrm{Cl}_{2}-\mathrm{C}_{2} \mathrm{H}_{5} \mathrm{MgBr}$ の系で窒素固定の反応速度的な研究を行

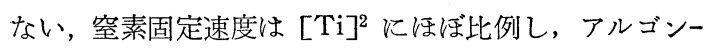
窒素混合系での窒素分圧の影響から, 反応は

または

$$
\mathrm{Ti}+\mathrm{N}_{2} \rightleftharpoons \mathrm{TiN}_{2}, \mathrm{TiN}_{2}+\mathrm{Ti} \longrightarrow \mathrm{NH}_{3}
$$

$$
2 \mathrm{Ti} \rightleftharpoons \mathrm{Ti}_{2}, \mathrm{Ti}_{2}+\mathrm{N}_{2} \longrightarrow \mathrm{NH}_{3}
$$

といった機構を提唱している.

Brinzinger ${ }^{(17)}$ は $\left(\mathrm{C}_{5} \mathrm{H}_{5}\right)_{2} \mathrm{TiCl}_{2}-\mathrm{C}_{2} \mathrm{H}_{5} \mathrm{MgCl}$ 系について ESR を測定し, Ti/Mg 比が 10 倍の際の生成黒褐色溶 液では, $g=1.993$ に強度比 $1: 2: 1$ のファインストラ クチャーをもつ三重線シグナルを認め, この強度は低温 ほど弱くなることを報じている。また， $\mathrm{C}_{2} \mathrm{D}_{5} \mathrm{MgBr}$ を用 いると, このシグナルの強度は減少して, 完全には分裂 しない五重線が現われる。 また, 反応液を塩酸で分解す ると水素ガスが発生し, もとの $\left(\mathrm{C}_{5} \mathrm{H}_{5}\right)_{2} \mathrm{TiCl}_{2}$ となるこ とから，複核ハイドライドの存在を推定している。また， 反応系の ESR の追跡などから，下記の機構を提案した.

しかし, Shilov ら ${ }^{(18)} は \mathrm{C}_{2} \mathrm{D}_{5} \mathrm{MgBr}$ を用いた際, 生成 アンモニア中にDのないことから $\mathrm{Ti}-\mathrm{C}_{2} \mathrm{D}_{5}$ を経て Ti-D の生成する機構を否定している. 同種の研究は HenriciOlivé らによっても行なわれ， ESR 測定から活性種は

$$
\left[\left(\mathrm{C}_{5} \mathrm{H}_{5}\right)_{2} \mathrm{Ti}^{\mathrm{II}}\left\langle{ }_{\mathrm{H}}^{\mathrm{H}}\right\rangle \mathrm{Ti}^{\mathrm{II}}\left(\mathrm{C}_{5} \mathrm{H}_{5}\right)_{2}\right]^{-}
$$

で, $\mathrm{N}_{2}$ は Ti而 のほうに固定されるとしている.

また, 彼らは $\left(\mathrm{C}_{5} \mathrm{H}_{5}\right) \mathrm{TiCl}_{2}$-アルカリ金属ナフタリンー
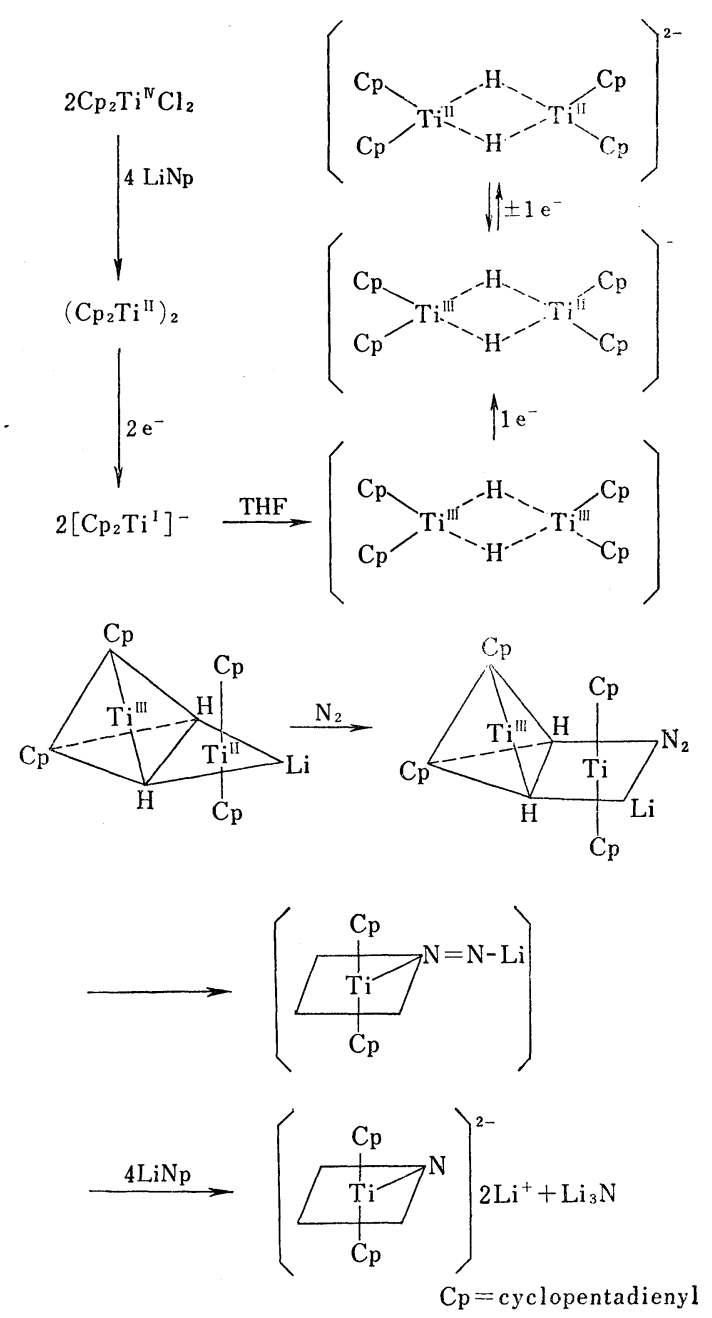

THF 系での検討から，上図のような機構を提案している.

この機構では, 生成した複核チタン八イドライドの $\mathrm{Ti}$ ㅍ $\mathrm{N}_{2}$ か配位し $\mathrm{Ti}-\mathrm{Li}$ 結合に挿入し, $\mathrm{Ti}-\mathrm{N}=\mathrm{N}-\mathrm{Li}$ の状態を経て反応が進むとしている。

$$
2\left(\mathrm{C}_{5} \mathrm{H}_{5}\right)_{2} \mathrm{TiCl}_{2} \stackrel{2 \mathrm{C}_{2} \mathrm{H}_{5} \mathrm{MgCl}}{\longrightarrow} 2\left(\mathrm{C}_{5} \mathrm{H}_{5}\right)_{2} \mathrm{Ti}\left\langle\chi_{\mathrm{Et}} \stackrel{\mathrm{Cl}}{-\mathrm{C}_{2} \mathrm{H}_{5}} \longrightarrow\left[\left(\mathrm{C}_{5} \mathrm{H}_{5}\right)_{2} \mathrm{TiCl}\right]_{2} \stackrel{2 \mathrm{C}_{2} \mathrm{H}_{5} \mathrm{MgCl}}{\longrightarrow} 2\left(\mathrm{C}_{5} \mathrm{H}_{5}\right)_{2} \mathrm{TiC}_{2} \mathrm{H}_{5} \longrightarrow\left[\left(\mathrm{C}_{5} \mathrm{H}_{5}\right)_{2} \mathrm{TiH}\right]_{2}\right.
$$

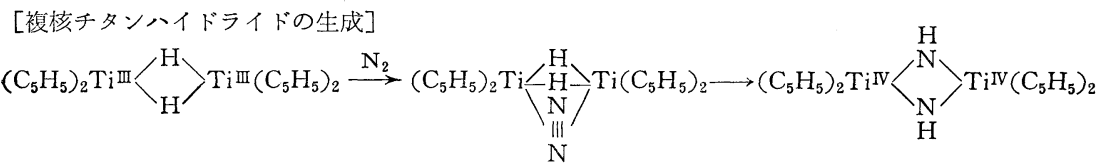

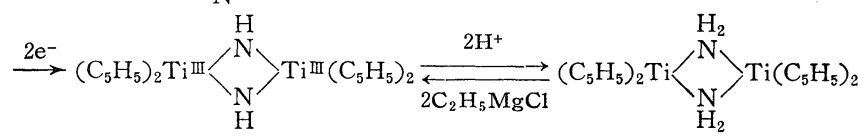

$$
\begin{aligned}
& \stackrel{2 \mathrm{HCl}}{\longrightarrow}\left(\mathrm{C}_{5} \mathrm{H}_{5}\right)_{2} \mathrm{Ti}\left\langle{ }_{\mathrm{Cl}}^{\mathrm{Cl}}>\mathrm{Ti}\left(\mathrm{C}_{5} \mathrm{H}_{5}\right)_{2}+2 \mathrm{NH}_{3}\right.
\end{aligned}
$$




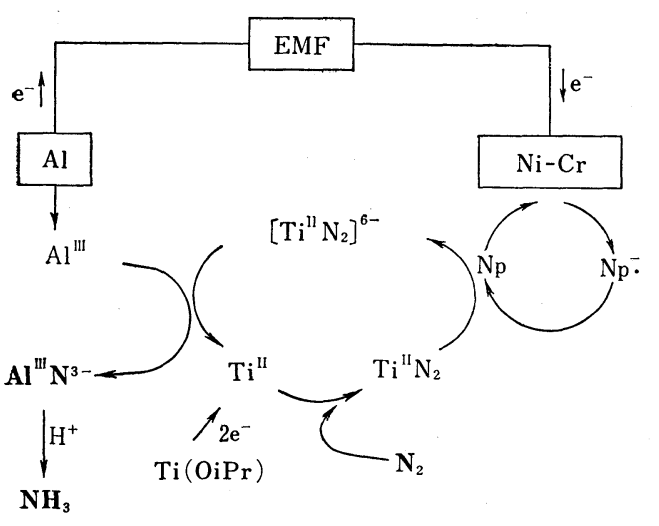

図 3 電解反応との組合せによるサイクル $\mathrm{iPr}=$ isopropyl, $\mathrm{Np}=$ naphthalide.

以上の機構解明と並行して，この反応を使用金属量以 上にアンモニアが生成するような，すなわち反応をりサ イクルする方法も検討されている。 van Tamalen ${ }^{(19)}$ は, 陽極にアルミニウム板, 院極にクロム板を用い, 溶 媒として 1,2-ジメトキシェタン, 窒素固定相として $\mathrm{Ti}(\mathrm{OiPr})_{4}$ を用い, 両極の電子のキャリヤーとしてナフ タリン- $\mathrm{Al}(\mathrm{OiPr})_{3}$ を溶液に加光, 窒素ガスをゆっくり 通じて 11 日間 $40 \mathrm{~V}$ で電解を行ない, 触媒系での電子 授受を電極反応とすることにより，Ti のモル数に対し て 610\% のアンモニアの生成を得ている（図 3）.この ように, この種の反応では合成化学的に窒素固定と同調 する電子供与系のサイクルを組むことが解決すべき問題 となる。

現在, $\mathrm{Ti}$ 系の反応では $\mathrm{Ti}-\mathrm{N} \equiv \mathrm{N}$ の活性化は認められ ず,むしろ Ti-N の形でとりこまれるとされる報告もあ るが，まだ不明な点が多い。

\section{2 窒素錯体の合成}

過去 3 年間に, 分子状空素を配位させた金属錯体はか なりの数が見いだされている.その金属種も図4 に示す ごとくであり, 遷移金属のほとんどについて, 原理的に その生成が可能なものの例があげられるのも間もないと 思ら。

また，現在までに合成された窒素錯体の代表的な IR

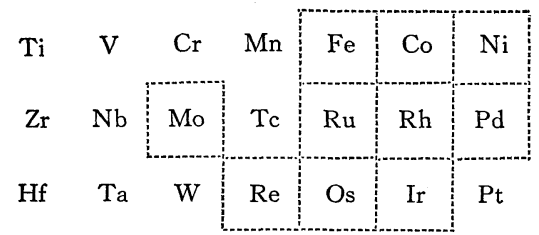

図 4 窒素錯体の合成された元素 図中の……で囲んだ箇所は，錯体の合成さ れたものを示す。
表 4 窒 素 錯 体

\begin{tabular}{|c|c|c|c|}
\hline 錯 & $\nu_{(N \equiv N)}$ & $\nu\left(M-N_{2}\right)$ & 文献 \\
\hline$\left(\mathrm{Ph}_{3} \mathrm{P}\right)_{2} \operatorname{Ir}\left(\mathrm{N}_{2}\right)(\mathrm{Cl})-$ & & & \\
\hline$\left(\begin{array}{c}\mathrm{R} \\
\mathrm{RO}_{2} \mathrm{C}\end{array}\right.$ & 2190 & & 20 a ) \\
\hline$\left(\mathrm{Ph}_{3} \mathrm{P}\right)_{2} \operatorname{Ir}\left(\mathrm{N}_{2}\right) \mathrm{Cl}$ & 2095 & & " \\
\hline$\left[\mathrm{Ru}\left(\mathrm{NH}_{3}\right)_{5} \mathrm{~N}_{2}\right]\left(\mathrm{PF}_{6}\right)_{2}$ & 2167 & 474 & $20 \mathrm{~b})$ \\
\hline$\left[\mathrm{Ru}\left(\mathrm{NH}_{3}\right)_{5} \mathrm{~N}_{2}\right]\left(\mathrm{BF}_{4}\right)_{2}$ & 2144 & 487 & $"$ \\
\hline$\left[\mathrm{Ru}\left(\mathrm{NH}_{3}\right)_{5} \mathrm{~N}_{2}\right] \mathrm{I}_{2}$ & 2129 & 489 & $"$ \\
\hline$\left[\mathrm{Ru}\left(\mathrm{NH}_{3}\right)_{5} \mathrm{~N}_{2}\right] \mathrm{Br}_{2}$ & 2114 & 499 & $"$ \\
\hline$\left[\mathrm{Ru}\left(\mathrm{NH}_{3}\right)_{5} \mathrm{~N}_{2}\right] \mathrm{Cl}_{2}$ & 2105 & 508 & $"$ \\
\hline $\mathrm{Ru} / \mathrm{THF} / \mathrm{N}_{2}$ & 2140 & & " \\
\hline$\left[\mathrm{Os}\left(\mathrm{NH}_{3}\right)_{5} \mathrm{~N}_{2}\right]\left(\mathrm{BPh}_{4}\right)_{2}$ & 2061 & 520 & 20c) \\
\hline$\left[\mathrm{Os}\left(\mathrm{NH}_{3}\right)_{5} \mathrm{~N}_{2}\right]\left(\mathrm{BF}_{4}\right)_{2}$ & 2055 & 529 & " \\
\hline$\left[\mathrm{Os}\left(\mathrm{NH}_{3}\right)_{5} \mathrm{~N}_{2}\right]\left(\mathrm{ClO}_{4}\right)_{2}$ & 2051 & 531 & $"$ \\
\hline$\left[\mathrm{Os}\left(\mathrm{NH}_{3}\right)_{5} \mathrm{~N}_{2}\right] \mathrm{I}_{2}$ & 2033 & 533 & $"$ \\
\hline$\left[\mathrm{Os}\left(\mathrm{NH}_{3}\right)_{5} \mathrm{~N}_{2}\right] \mathrm{Br}_{2}$ & 2028 & 540 & $"$ \\
\hline$\left[\mathrm{Os}\left(\mathrm{NH}_{3}\right)_{5} \mathrm{~N}_{2}\right] \mathrm{Cl}_{2}$ & 2010 & 546 & $"$ \\
\hline$\left(\mathrm{Ph}_{3} \mathrm{P}\right)_{3} \mathrm{Co}\left(\mathrm{N}_{2}\right)$ & 2088 & & 10) \\
\hline$\left(\mathrm{Ph}_{3} \mathrm{P}\right)_{3} \mathrm{Co}\left(\mathrm{N}_{2}\right) \mathrm{H}$ & 2088 & & 11) \\
\hline$\left[\left(\mathrm{PCH}_{3} \mathrm{C}_{6} \mathrm{H}_{4}\right)_{3} \mathrm{P}\right]_{3} \mathrm{Co}\left(\mathrm{N}_{2}\right) \mathrm{H}$ & 2073 & & 20d) \\
\hline$\left[\left(\mathrm{C}_{6} \mathrm{H}_{5}\right)_{2} \mathrm{C}_{2} \mathrm{H}_{5} \mathrm{P}\right]_{3} \mathrm{Co}\left(\mathrm{N}_{2}\right) \mathrm{H}$ & 2060 & & " \\
\hline$\left[\left(n-\mathrm{C}_{4} \mathrm{H}_{9}\right)_{3} \mathrm{P}\right]_{3} \mathrm{Co}\left(\mathrm{N}_{2}\right) \mathrm{H}$ & 2032 & & $"$ \\
\hline$\left[\left(\mathrm{C}_{2} \mathrm{H}_{5}\right)_{3} \mathrm{P}\right]_{3} \mathrm{Co}\left(\mathrm{N}_{2}\right) \mathrm{H}$ & 2033 & & $"$ \\
\hline$\left[\left(\mathrm{C}_{6} \mathrm{H}_{5}\right)_{2} \mathrm{C}_{2} \mathrm{H}_{5} \mathrm{P}\right]_{3} \mathrm{Fe}\left(\mathrm{N}_{2}\right) \mathrm{H}_{2}$ & 2055 & & 24) \\
\hline$\left[\left(\mathrm{Ph}_{3} \mathrm{P}\right)_{2} \mathrm{MoN}_{2} \mathrm{CH}_{3} \mathrm{C}_{2} \mathrm{H}_{5}\right]_{n}$ & 2000 & & 25) \\
\hline$\left(\mathrm{Ph}_{2} \mathrm{PCH}_{2} \mathrm{CH}_{2} \mathrm{PPh}_{2}\right)_{2} \mathrm{Mo}\left(\mathrm{N}_{2}\right)_{2}$ & 1970 & & 26) \\
\hline$\left(\mathrm{PMe}_{2} \mathrm{Ph}\right)_{4} \mathrm{ReClN}_{2}$ & 1925 & & $20 \mathrm{e})$ \\
\hline$\left(\mathrm{PPh}_{3}\right)_{2} \mathrm{RhClN}_{2}$ & 2152 & & 20f) \\
\hline
\end{tabular}

表 5 結合エネルギー ( $\mathrm{kcal} / \mathrm{mole})$

\begin{tabular}{|c|c|c|}
\hline $\left.\begin{array}{lr}C-C & 80 \\
C=C & 145\end{array}\right) 65$ & $\left.\begin{array}{lr}\mathrm{C}-\mathrm{N} & 73 \\
\mathrm{C}=\mathrm{N} & 147\end{array}\right) 74$ & $\left.\begin{array}{lr}\mathrm{N}-\mathrm{N} & 37 \\
\mathrm{~N}=\mathrm{N} & 100 \\
\mathrm{~N} \equiv \mathrm{N} & 225\end{array}\right) 125$ \\
\hline
\end{tabular}

スペクトルを表 4 に示す(20). いずれの錯体でも， $\nu_{\mathrm{N}_{2}}$ は 遊離窒素の $\nu_{\mathrm{N}_{2}}$ に比してかなり低波数にシフトしており， $\mathrm{N} \equiv \mathrm{N}$ 結合がゆるんでいることが推定される. Decius に よれば, $\mathrm{N}-\mathrm{N}$ 結合の力の定数と解離エネルギーが直線 関係にあるとしているが，これにより，たとえばCo $\left(\mathrm{PPh}_{3}\right)_{3} \mathrm{~N}_{2} \cdot \mathrm{H}$ の場合の $\nu_{\mathrm{N}_{2}} 2088 \mathrm{~cm}^{-1}$ から力の定数を求 め, 次いで解離エネルギーを計算すると, 遊離の場合よ りも約 $55 \mathrm{kcal} / \mathrm{mole}$ 結合がゆるんだことになる。しか し, 現在種々な窒素錯体の配位窒素を還元する試みが行 なわれているが，いずれの錯体に和いても反応しえない でいる、これは, 配位により $55 \mathrm{kcal} / \mathrm{mole} の$ 活性化が 与えられたとはいえ, 窒素分子の解離エネルギーは 225 $\mathrm{kcal} / \mathrm{mole}$ と非常に大きく，とくに三重結合の1 2及゙ ず切断される段階が困難であることによろう（表 5).

しかし，一方このような IR スペクトルからの推定で 窒素分子の反応性を論じてよいか否かに凩䦗題がある。 
筆者らの研究室で合成した $\mathrm{Mo}\left(\mathrm{Ph}_{2} \mathrm{PCH}_{2} \mathrm{CH}_{2} \mathrm{PPh}_{2}\right)\left(\mathrm{N}_{2}\right)_{2}$ 錯体は, $\nu_{\mathrm{N}_{2}}$ は $1860 \mathrm{~cm}^{-1}$ と, 従来報告されているるの の中でも最も低波長にシフトしているが，このものは熱， 空気に対しても他のものに比べて抜群に安定である.

窒素分子をより活性化する試みとして，2つの金属 にはさまれた状態を形成することも試みられている。 $\left[\left(\mathrm{NH}_{3}\right)_{5} \mathrm{Ru}-\mathrm{N} \equiv \mathrm{N}-\mathrm{Ru}\left(\mathrm{NH}_{3}\right)_{5}\right]^{4+}$ 錯体は, $\mathrm{Ru}\left(\mathrm{NH}_{3}\right)_{5} \mathrm{Cl}_{3}$ を亜鉛アマルガムで還元して合成する。

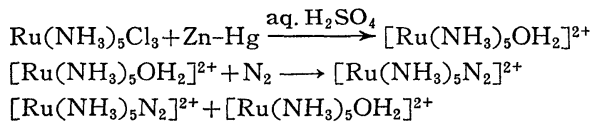

$$
\begin{array}{cccc}
\mathrm{H}_{3} \mathrm{~N} & \mathrm{NH}_{3} & \mathrm{H}_{3} \mathrm{~N} & \mathrm{NH}_{3} \\
\mathrm{H}_{3} \mathrm{~N}-\mathrm{Ru}-\mathrm{N} \equiv \mathrm{N}-\mathrm{Ru}-\mathrm{NH}_{3} \\
\mathrm{H}_{3} \mathrm{~N} \mathrm{NH}_{3} & \mathrm{H}_{3} \mathrm{~N} \quad \mathrm{NH}_{3}
\end{array}
$$

の形をし， Ru-N三N-Ru は IR 不活性であるが, ラマン スペクトルで $2100 \mathrm{~cm}^{-1}$ に吸収を示す(21).

また，異種金属間にはさまれた窒素錯体

$\mathrm{ReClN}_{2}\left(\mathrm{PMe}_{2} \mathrm{Ph}\right)_{4}+\mathrm{MoCl}_{4} \cdot 2 \mathrm{Et}_{2} \mathrm{O}$

$\nu_{\mathrm{N}_{2}} 1922 \mathrm{~cm}^{-1}$

$\longrightarrow\left[\left(\mathrm{PMe}_{2} \mathrm{Ph}\right)_{4} \mathrm{ClRe}-\mathrm{N} \equiv \mathrm{N}-\mathrm{MoCl}_{4}\left(\mathrm{PEtPh}_{2}\right)\right]$ $\nu_{\mathrm{N}_{2}} 1680 \mathrm{~cm}^{-1}$

も合成され(22), このものの配位窒素は IR スペクトルで $1810 \mathrm{~cm}^{-1}$ と低波長へのシフトをしているが，還元反応 はうけない。しかし，一方このような一群の窒素錯体の 合成により, 窒素分子は配位子としての機能を認められ たわけである.配位 $\mathrm{N}_{2}$ と $\mathrm{CO}$ の比較を表 6 に示す.

\section{表 6 配位状態での配位子の IR スペクトル $\left(\mathrm{cm}^{-1}\right)$}

\begin{tabular}{c|cccc}
\hline $\mathrm{L}$ & $\begin{array}{c}\mathrm{N} \equiv \mathrm{N} \\
(2330)\end{array}$ & $\begin{array}{c}\mathrm{C} \equiv \mathrm{O} \\
(2143)\end{array}$ & $\begin{array}{c}\mathrm{Ph}-\mathrm{C} \equiv \mathrm{N} \\
(2231)\end{array}$ & $\begin{array}{c}\mathrm{CH}_{3} \mathrm{C} \equiv \mathrm{N} \\
(2255)\end{array}$ \\
\hline $\mathrm{IrCl}(\mathrm{L})\left(\mathrm{PPh}_{3}\right)_{2}$ & 2105 & 1962 & & \\
& $\Delta(225)$ & $\Delta(181)$ & & \\
$\mathrm{CoH}(\mathrm{L})\left(\mathrm{PPh}_{3}\right)_{3}$ & 2088 & 1910 & & 2210 \\
& $\Delta(242)$ & $\Delta(233)$ & & $\Delta(45)$ \\
$\mathrm{Ru}\left(\mathrm{NH}_{3}\right)_{5} \mathrm{LX}_{2}$ & 2129 & 1955 & 2194 & \\
& $(\mathrm{X}=\mathrm{I})$ & $(\mathrm{X}=\mathrm{I})$ & $(\mathrm{X}=\mathrm{Br})$ & \\
& $\Delta(201)$ & $\Delta(188)$ & $(\Delta 37)$ & \\
\hline
\end{tabular}

ここで， $\triangle$ は遊離の状態と配位状態での IR スペクトル の波長差を示して和り， $\mathrm{N}_{2}$ のほうがCoよりより強い $\pi$-acceptor であることを示唆している。このような知 見から，窒素分子を金属に配位させるためには，錯体の 中心金属原子上にできるだけ高い電子密度が得られるよ らにすることが必要となる。しかしながら, 現在, この 種の錯体の合成の基本的原理はなく，いっそう暗中模索 にならざるをえない。

配位子を例にあげよう。すでに述べたように，Co(ac ac) ${ }_{3}$ をトリフェニルホスフィン存在下, $\mathrm{AlEt}_{2}(\mathrm{OEt})$ で
$\mathrm{N}_{2}$ 下で還元することにより $\mathrm{Co}\left(\mathrm{PPh}_{3}\right)_{3} \mathrm{~N}_{2} \cdot \mathrm{H}$ が得られ た.この際，配位子として用いる有機燐化合物を変化さ せると, 一般に $\mathrm{PR}_{3}$ では錯体は生成するが, $\mathrm{PR}_{2} \cdot \mathrm{H} て ゙$ は $\mathrm{Co}\left(\mathrm{PR}_{2} \mathrm{H}\right)_{4} \mathrm{H}$ といったハイドライドとなる. 金属と して $\mathrm{Ni}(\mathrm{acac})_{2}$ を用いた同様の反応では,トリフェニル ホスフィンでは得られず, トリシクロヘキシルホスフィ ンを用いた場合, $\left.\left[(\mathrm{P}+\langle\overline{\mathrm{H}}\rangle)_{3}\right)_{2} \mathrm{NiN}_{2}\right]_{2}$ といった複核 構造 (23)のものとして得られる. $\mathrm{Fe}(\mathrm{acac})_{3}$ の場合, トリ フェニルホスフィンは不可, トリシクロホスフィンでは 構造不明の油状含窒素錯体となる。この場合は, むし ろ Sacco の還元方式，すなわち $\mathrm{FeL}_{n} \mathrm{X}_{3}$ を出発物質之 して $\mathrm{NaBH}_{4}$ などで還元することにより，目的の錯体が できる $\left[\mathrm{FeH}_{2} \mathrm{~N}_{2}\left(\mathrm{PEtPh}_{2}\right)_{3}, \nu_{\mathrm{N}_{2}} 2055 \mathrm{~cm}^{-1}\right]^{(24)}$. このよ うに，金属種により，また安定化配位子，還元法とによ り，非常に微妙な影響が示される。

生体内での金属 site はポリマー，すなわちポリペプ チド上に存在するわけで, 配位子の有機燐を互いに連結 させたものを用いるとする。Co の場合，二座配位子 の $\mathrm{Ph}_{2} \mathrm{PCH}_{2} \mathrm{CH}_{2} \mathrm{PPh}_{2}$ を用いると, $\mathrm{HCo}\left(\mathrm{Ph}_{2} \mathrm{PCH}_{2} \mathrm{CH}_{2}-\right.$ $\left.\mathrm{PPh}_{2}\right)_{2}$ のハイドライド錯体となる. $\mathrm{R}_{2} \mathrm{PCH}_{2} \mathrm{CH}_{2}$ $\mathrm{PRCH}_{2} \mathrm{CH}_{2} \mathrm{PR}_{2}$ または $\mathrm{CH}_{3} \mathrm{C}\left(\mathrm{CH}_{2} \mathrm{PPh}_{2}\right)_{3}$ といった三座 配位子を用いれば，より安定に錯体が生成するかと予想 して試みるとすべてクラスターとなり，とくに Co 上の $\mathrm{N}_{2}$ とハイドライドがシスになるように注意しても，む しろ $\mathrm{N}_{2}$ が配位しなくなる。ところが， $\mathrm{Mo}(\mathrm{acac})_{3}$ を $\mathrm{AlEt}_{3}$ で還元する系では, トリフェニルホスフィンでは $\mathrm{Mo}\left(\mathrm{N}_{2}\right)\left(\mathrm{PPh}_{3}\right)_{2}$ (solvent) といった会合状態になり(25), かなり不安定であるが，二座ホスフィンではきわめて安 定な錯体 $\mathrm{Mo}\left(\mathrm{Ph}_{2} \mathrm{PCH}_{2} \mathrm{CH}_{2} \mathrm{PPh}_{2}\right)_{2}\left(\mathrm{~N}_{2}\right)_{2}$ となる ${ }^{(26)}$. 誠 に意のままにならないこと和びただしい次第である。

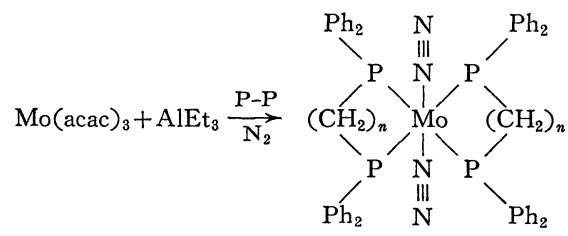

二座の燐原子をつなぐ $-\mathrm{CH}_{2}$ - の数を $1,2,3,4$ と変化 させると， $n=4$ 以上では窒素錯体は生成しない。これ は, P-Mo-P の配位の角度のひずみが Mo- $\mathrm{N}_{2}$ 結合を不 安定化するためであろら。

以上のように，分子状窒素からの活性化の検討とと末 に, 窒素同化過程のモデルとして, Parshal1(27), Greer. ら ${ }^{(28)}$ の研究者が金属ハイドライドによるジアゾニウム 塩などの還元反応を行なっている。 


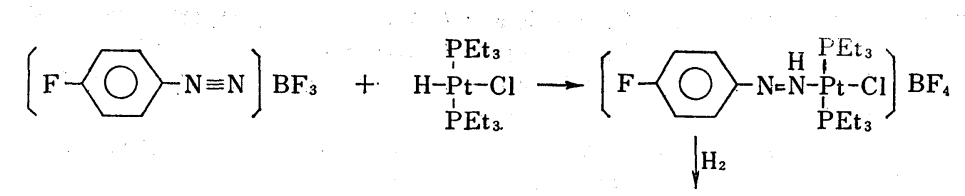

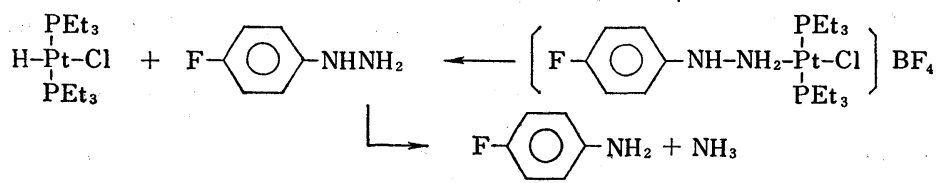

属により行なわれると推定され, 金 属種にもよるが, ほぼ $2000 \mathrm{~cm}^{-1}$ 付 近にIR 吸収を示す水素の活性化は, 配位子の $\pi$ 電子系で行なわれると推 定されている.この場合, $\mathrm{Me}-\mathrm{N} \equiv \mathrm{N}$. の吸収スペクトルからは, とくに他 の窒素錯体に比し異常な配位活性化 をうけているとは考えにくく，むし ろ活性な $\mathrm{Me}-\mathrm{N} \equiv \mathrm{N}$ と活性な水素が同一の共役軌道系に あり, これが次の付加反応へきわめて都合よく機作して いるのではないかと考えられる。

生物系での反応で, いわゆるコンサーテッドメカニズ ムとよばれる機構が提案されている。これは，A，B の 反応物が反応する際, site の周辺基質が

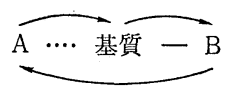

というように両者の活性化に関与しつつ A-B の反応を たすけている。このような考えに関連して, 従来の金属一

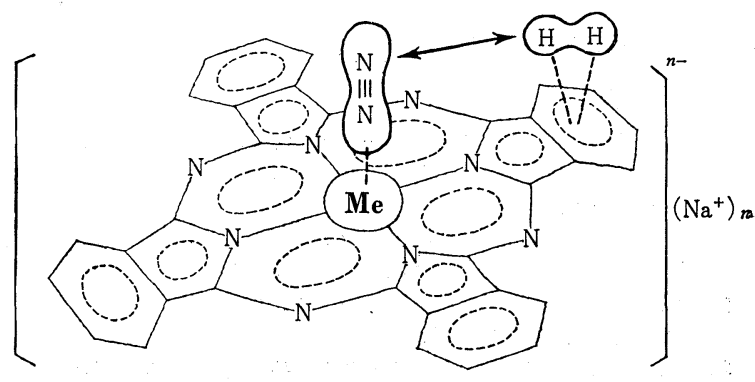

フタロシアニン系 CT 触媒でのアンモニア合成想像図

分子状窒素の反応では, $\mathrm{Me}-\mathrm{N} \equiv \mathrm{N}$ と $\mathrm{Me}-\mathrm{H}$ との単なる dipole interaction 的な接触でなく, さらに同一分子軌。 道中でこのような形がとられる。または, 活性化状態で の新しい共役系の形成といったことが必要になるのかも しれない.また,これが単に酵素 site モデルといら以上 に,もら1つの明らかにすべき秘密をかくしているとも. 考觉られ。

\section{5. お わ り}

以上, 雑然とした状態ではあるが, 最近の窒素固定に ついての化学の分野での動向を筆者の感ずるままに紹介 した．筆者はこれらの研究が直らに複雑精緻な生体反応. に対応したものとは毛頭考えていないし, また研究の過 程で生体反応の精緻さをますます深く感じさせられてい る.ところで, 筆者が行なっている研究の1つに合成テ ルペンの研究がある. 自然界でインプレン単位構造を 
もった生成物は多様であって，たとえばゴム樹液では cis-1-4 ポリイソプレンとして，また松柏科ではテルペ ンとして，さらに，香油，色素などとして存在する，イ ソプレン構造の導入過程は別として，その連鎖過程に㗢 く，たとえば酵素のほんのわずかな差が，イソプレンの ポリマーとして，また二，三量体として植物中に保たせ たのではないか。実は，このような単純，ある場合には 誤り多い発想を基にして, cis-1-4 ポリイソプレンの工 業触媒である遷移金属を変性することにより，構造の規 制された二，三量体を選択的に合成する触媒系を見いた した。もちろん，生成物は天然のテルペンとは構造的に 異なる場合が多いが，異なる次元の科学で類似のパター ンが形成しらるのである．筆者の窒素錯体の着手点もこ れに関連した研究から生じたのであるが，このようにし て絹を夢見てナイロンが生まれるようなことがあっても よいと考光る，また一方，錯体合成といった事柄のつみ 重齐が，その結合，活性化を明らかにし，生体における 咥素固定の解析へのいくばくかの知見を与え，かつこれ らから将来さまざまの現象がとさほぐされ再編成されて， 科学の実のむすぶのを待望したい.

\section{文 献}

1) D. C. Smith : Coordin. Chem. Rev., 3, 429 (1968). G. Henrici-Olivé and S. Olive : Angew. Chem. Internat. Edit., 8 (9), 650 (1969).

A. D. Allen and F. Bottomley : Accounts of Chem. Research I, 1968, p. 360 .

2) R. W.F. Hardy and R.C. Burns: Ann. Rev. Biochem., 37, 331 (1968).

3) R. W.F. Hardy et al. : Biochem. Biophys. Res. Commun., 20, 539 (1965).

4) T. Nakata et al. :J. Catalysis., 4, 631 (1965).

5) M.E. Vol'pin and V. B. Shur : Dokl. Akad. Nauk. SSSR, 156, 1102 (1964).

6) T. Saito, Y. Uchida et al.:J. Organomettalic Chem., 6, 572 (1966).

7) A.D. Allen and C. J. Senoff :Chem. Commun., 1965, 621.

8) G. N. Nechiporenko and A. E. Silove et al.: Dokl. Akad. Nauk. SSSR, 164, 1062 (1965).

9) A. Yamamoto and S. Ikeda et al. : Chem. Commun., 1967,79

10) A. Misono, Y. Uchida et al.: Bull. Chem. Soc. Japan, 40, 700 (1967)

11) A. Sacco and M. Rossi : Chem. Commun., 1967, 316.

12) G. W. Parshall :J. Am. Chem. Soc., 90, 1669 (1968).

13) B. R. Davis and J.A. Ibers : Inorg. Chem., 8, 2719 (1969).

14) E. E. van Tamelen, R. B. Fechter and S. W. Schneller:J. Am. Chem. Soc., 91, 7196 (1969).

15) M. E. Vol'pin and V.B.Shur: Dokl. Akad. Nauk. SSSR, 168, 1873 (1966).

16) R. Maskill and J.M.Pratt : Chem. Commun., 1967, 956.

R. Maskill and J.M. Pratt :J. Chem. Soc. (A), 1914 (1968).

17) H. Brinzinger : J. Am. Chem. Soc., 88, 4305, 4307(1966) H. Brinzinger : J. Am. Chem. Soc., 89, 6871 (1967)

18) A. E. Shilov et al. : Dokl. Akad. Nauk. SSSR, 164, 1062 (1965).

19) E. E. van Tamalen and D. A. Seeley : J. Am. Chem. Soc., 91, 1593 (1969).

20) a. J.P. Collman and J.W. Kang:J. Am. Chem. Soc., 88, 3459 (1966).

b. A. D. Allen and F. Bottomley et al. :J. Am. Chem. Soc., 89, 5595 (1967).

c. A. D. Allen and J. R. Stevens : Chem. Commun., 1967, 1147.

d. A. Misono and Y. Uchida et al. : J. Inorg. Chem., 8, 168 (1969).

e. J. Chatt and J.R. Dilworth : Chem. Commun., 1969, 687.

f. L. Yu. Uklin and Yu. A. Shvetsov: Izv. Akad. Nauk. SSSR, Ser. Khim, 957 (1967).

21) I. M. Treitel, M. T. Flood, R. E. Marsh and H. B. Cray :J. Am. Chem. Soc., 91, 6512 (1969).

22) J. Chatt and J. R. Dilworth : Nature, 224, 1201(1969).

23) P. W. Jolly and K. Jonas : Angew. Chem., 80, 705 (1968).

24) A. Sacco and M. Aresta : Chem. Commun., 1968, 1223.

25) M. Hidai, Y. Uchida and A. Misono: Chem. Com mun., 1969, 814.

26) M. Hidai, Y. Uchida and A. Misono: Chem. Com. mun., 1969, 1392.

27) G. W. Parshall : J. Am. Chem. Soc., 89, 1822 (1967).

28) M. L. H. Green and J. R. Sanders : Chem. Commun., 1967, 956.

29) M. Sudo, M. Ichikawa and K. Tamara : J. Phys. Chem., 73, 1174 (1969).

A new annual journal

\section{Advances in Biophysics}

Vol. 1, 1970

Editor

Masao Kotani

Editorial board

S. Ebashi K. Imahori

T. Isemura Y. Katsuki

J. Nagumo H. Noda

F. Oosawa E. Teramoto

J. Tomizawa

Secretary K. Maruyama

Contents

Y. Katsuki et al., The Lateral-line Organ of Shark as a Chemoreceptor

F. Egami et al., Ribonuclease $\mathrm{T}_{1}-$ Structure and Function-

S. Asakura, Polymerization of Flagellin and Polymorphism of Flagella

T. Iizuka and T. Yonetani, Spin Changes in Hemoproteins

200 pp. $¥ 2,000$

University of Tokyo Press

7-3-1 Hongo, Bunkyo-ku, Tokyo, 113

Telephon: Tokyo (811) 8814 